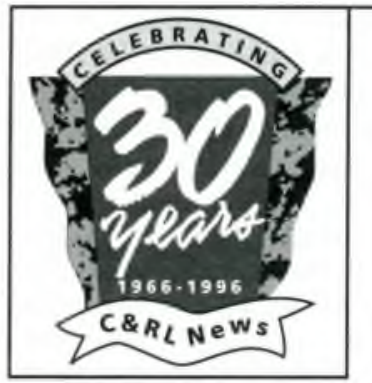

\title{
More than just news: C\&RL News at 30
}

\author{
By Edward G. Holley
}

\section{The evolution of $A C R L$ 's journal of record}

I

$n$ the annals of ACRL history, if there is one thing that academic librarians have agreed upon, it is the importance of their uniqueness among librarians and their fidelity to their association. Admittedly not all librarians feel that way. ACRL's membership, after reaching a high of 13,000, has declined to somewhere between ten and eleven thousand in recent years. Yet it remains ALA's largest division and, if measured against other library associations, ranks third in membership, below ALA itself and the Special Libraries Association.

\section{Waging battles}

Traditionally, ACRL was a complaining division, though it has never exercised the power in ALA that its membership cleserved. Members often bewailed the fact that the division was mistreated, but they rarely took steps to remedy that. One exception was ACRL's insistence on having its own journal, College \& Research Libraries ( $C E R L$ ). To maintain CERL, the division waged one last battle with ALA before the new dues structure in the mid-seventies gave the ALA divisions control over their own destiny, and hence over their own publications.

Stimulated by Dick Dougherty's editorial,
"Can Academic Librarians Afford College \& Research Libraries?" more than 80 persons expressed their outrage at ALA's mistreatment of the journal, i.e, its threatened lack of continued support, in the September 1971 CERL. The printed letters stated that $C E R L$ was the major contribution ALA made to ACRL's membership. In addition to support for its scholarly journal, ACRL members also expected their association to assert their rights in academia, to develop standards, and to publish monographs and other literature which would advance the interests of their profession. While they honored research and scholarship, they especially wanted their association to provide information about what's going on in the larger world that affects them and their libraries.

\section{Varied and vibrant}

To meet these expectations, the academic librarian over the years has welcomed four ACRL journals: $C E R L$, a journal devoted to research and scholarship; College E Research $\mathrm{Li}^{-}$

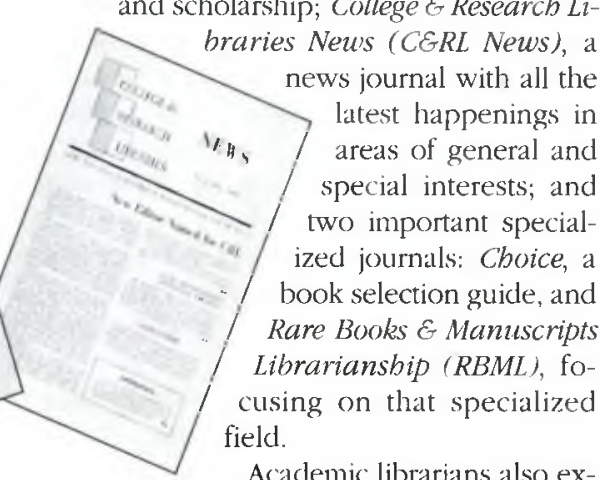
pected their association to publish monographs of a research nature (ACRL Monographs, 
now the Publications in Librarianship series) and of a practical, everyday variety (CLIP Notes), as well as standards and guidelines on perennial topics such as academic/faculty status, accreditation, statistics, etc. As Richard Werking observed, the ACRL publications program has provided us with "a varied and vibrant array of books, journals, and surveys" (CERL News, May 1995)

\section{Demands for information grow}

Beginning with CERL in 1939, the association inclucted within this journal book reviews, substantive articles, opinion pieces, and news of the field. With the explosive growth of academic libraries in the post World War II period, there was an increase in the amount of material needed "for the good of the order." The bimonthly CERL found it difficult to accommodate both serious scholarship and the general news needed by the membership. By the time a CERL issue appeared, the "news" was simply a matter of record rather than news. In addition. the amount of news expanded the size of the journal with significant increases in the cost of mailing.

The solution in 1966-67 was to create another publication which focused on association activities, presidential reports, news from the field, federal legislation, appointments, retirements, ohituaries, drafts of standards, etc. IMary Falvey chronicled the story of discussions leading to the News formation in "Publishing the Association Journal, January 1, 1962-December 31, 1966" ( CERL, November 1967).J Beginning as a modest supplement to the research journal, CERL News became the new outlet not only for information about the association but also about the wider world of academia. The need for keeping up with the news became more urgent as library support began to change from the glory days of the sixties into a period of static or declining budgets. Librarians also had to cope with the new costs of computerized information, especially those associated with national and regional online catalogs and databases

Still it was an exciting time to be an academic librarian. Amid the changes came the triennial ACRL conferences, which focused on programs rather than association business. With the change in the way ALA restructured its dues in the mid-seventies, ACRL could now be assured of the kind of revenue stream from membership dues that would guarantee its ability to carry out important new programs. The negotiations with Al.A were sometimes tense but ACRL has continued to be its largest and most active division.

\section{Perennial concerns}

What were the concerns that CGRL News addressed over the 30 years of its existence? The categories are as impressive as their concerns are perennial: the status of the academic librarian, the relationship of the academic library to its parent body, the need for new standards and guidelines, the relationship of libraries to the new technology, provision of services for distance learners, and, always, the status of the academic librarian in the academic community. Should they have faculty status, or academic status, or occupy some other role? How does the association influence the regional accrediting associations on these and other matters? Such topics have persisted since ACRL was founded and they sometimes have had positive results. CGRL News has also been a conveyer of important information about what is going on in higher education groups and how ACRL can do a better job of relating to those groups as well as their counterparts on campus.

CERL News has been especially important in giving the members a sense of their own worth. The various awards, especially the ACRL Academic/Research Librarian of the Year Award,

\section{Ups and downs}

By the early nineties CERL Neus had become a very large journal indeed. Having begun with 82 pages in 1967 , the magazine had reached 407 pages by 1982 , passed the 1,000 page mark in 1989 (the year of ACRL's 50 th birthday), and reached a high point of 1,116 pages in 1990! The next year saw a decline to 1,052 pages. a further decline to 752 pages in 1992 , and then back up to 830 in 1995. The prospect for 1996 may see the News again reach the thousand-page mark. Also in recent years the News has included an insert catalog of ACRL publications in two issues per year. To review the association's publishing record is to remind oneself of how far ACRL has come in adding significant research and professional titles to our knowledge base. 
often featured on the cover, and also the Hugh Atkinson Award, the Saur Award for best CERL article, the doctoral dissertation fellowship, Dudley BI Librarian of the Year, etc., all have received recognition in CERL News, usually with a statement about the awardee's contributions. Continuing education, especially with the advent of the computer, has also received considerable attention. And the advertising revenue for vacant positions, as well as display ads from library-related business, has generally made the News self-supporting.

\section{Hear it first here}

To be honest, CERL News is probably more read and/or scanned than CERL itself. In the News you hear it first (with the possible exception of the World Wide Web). In any case, for academic librarians who want to keep up in their field, the News has become the major source, from higher education to the campus, from book publications to networking. The Neus for some time now has also carried short but helpful articles of a professional nature.

Among the more interesting articles for this writer have been the opinion pieces. Especially interesting is the series "The Way I See It," which has included viewpoints of some of ACRL's most thoughtful members as well as those of leaders in higher education. I cite two interesting examples: Ralph Wolff's "Rethinking the Librarian's Role on Accreditation Teams" (July/ August 1992,) written by an accrediting association official, not a librarian; and Irene

\section{Leaders speak out}

Here is a sampling of the important information one can get by reading the Annual Reports published in CERL News.

"In the future, ACRL is likely to be different from what it is today. The impetus to work more closely with other organizations involved with higher education, and the changing role of librarians on college and university campuses, will contribute to making the organization more professional, more streamlined, and a force to be reckoned with in the arena of higher education."-Susan K. Martin, 56th president (December 1995)

"As I look to the year ahead, it is clear that academic librarians cannot conduct their business in isolation. Changing agendas in higher education, information technology, and education in general present major challenges."Althea Jenkins, ACRL executive director (November 1992)

"One of our most persistent challenges, then, is to develop a clearer vision of our role and convey it persuasively and compellingly to others: to our faculty colleagues, to computing center staff, to senior administrators, to state legislators and boards of regents-indeed, to all of our real and presumptive partners in higher education."-William A. Moffett (July/August 1990)
"The mission of ACRL is to represent academic and research libraries. This includes all types of academic libraries-community and junior college, college, and university - as well as comprehensive and specialized research libraries and their professional staffs. ACRL also has as its mission the enhancement of library service, in the broadest sense, to the academic and research communities."-Quote from "Statement of Responsibility" in Le Moyne W. Anderson's presidential report (September 1980)

"ACRL publications continue to be among the division's most important and appreciated programs."-Connie R. Dunlap (July/August 1977) (Ed. note: Dunlap also announced the forthcoming monograph. Libraries for Teaching, Libraries for Research: Essays for a Century, edited by Richard Jobnson, and written for the Al.A Centennial.)

"Substantial progress was achieved in the area of developing standards for community college and college libraries. . . The pursuit of the elusive goal of full faculty status for all academic librarians continued to be a major ACRL goal and the problem of governance in all its intriguing complexity was debated and explored through traditional and nontraditional media."-H. William Axford (July/August 1975) 
Hoadley's "Customer Service? Not Really," (March 1995). A number of individuals have deplored the fact that librarjans talk too much to themselves. President William Moffett's guest editorial, "Talking to Ourselves," in the November 1989 $C E R L$, reiterated the view of some of his predecessors. His song was surely the same tune, umpteenth verse. The News has tried to bring other persons from outside the profession into discussions and, of course, the ALA Washington Office provides a regular update on the national scene, including comments from individuals in Congress.

\section{Reports of the presidents}

Let me also give credit to some of the presidents' annual reports as well as those of the executive directors. Like most reports, they probably are not on the reading list of most members, though they should be. I cite not only Louise Giles's report of $1975-76$, but also her article, "The Impact of the New Dues Structure," the same year. Her presidency was not only the year of the ALA centennial conference but also the transition to the new dues structure. Her tragic death that same year was a great loss to ACRL. (See October 1996, page 611, for a reprint of Giles's obituary.)

Le Moyne Anderson's report in 1979-80 cited ALA Council's approval, at long last, of the ACRL mission statement, as noteworthy. The following year David Weber discussed the importance of planning and the continuing discussions among ALA and its divisions about the operating agreement, as well as the evolving strategic plan. By the time of Hannelore Rader's report in 1986-87, computers were beginning to gain some attention but the big news of the year

What can one say about
C\&RL News on its 30th
birthday? That the basic
issues remain, but they
have been joined by
newer concerns. ... . have had a decided impact not only on the association but also on the publications. (See September 1996, page 513, for a list of CERL News editors.)

\section{Expanding issues}

The topics addressed in CERL News have not changed so much as they have expanded, especially in relationship to technol-

ogy. There have been new or revised standards and guidelines, and stories on campus/library relationships, governance, federal and state legislation, conference and association activities, news about libraries including appointments, awards, gifts and grants, retirements, deaths, collections, and buildings. A major recent change has been the introduction of short opinion pieces and brief descriptions of new monographs that might be of interest but not worthy of a full-blown review in CGRL. Clearly there is also a lot of information on technology, OCLC, regional networks, RLG, Washington, etc.

The News also provides data on official ACRL business such as election results, including the number voting for each candidate, though these may be of interest to relatively few members. In recent years the total vote count for vicepresident/president-elect has ranged from roughly $2,000-2,500$, only 20 to $25 \%$ of the total membership.

\section{We have excelled}

What can one say about CERL News on its 30th birthday? That the basic issues remain, but they was the imminent appearance of Books for College Libraries, 3rd ed.

Certainly the reports of the ACRL executive directors merit careful reading by the members. They and the editors of ACRL's publications cccurred. There is likely to be a continuing need for the News, both to keep us abreast of changes and and just occasionally to remind us of the past: that somehow we coped and even at times we have excelled. Per aspera ad astra! 